\title{
Issues of Concern for Restaurant Owners and
} Managers

\author{
by CATHY A. ENZ
}

Human resources continues to be the most troubling issue for U.S. restaurant owners and operators. When 448 restaurateurs were given the chance to state their top concerns, they chose finding and keeping competent employees, closely followed by a constellation of concerns relating to government regulation, taxation, and legal liability. Other issues that respondents cited were ensuring safe food handling, finding effective marketing strategies, and staying ahead of competitors in a tight economic environment.

Keywords: restaurant managers; restaurant owner concerns; problems in hospitality; key issues; human resources management

I $\mathrm{n}$ a time of economic instability and international turbulence, it is worth examining what issues most worry restaurant owners and operators in the United States. The restaurant industry finds itself struggling with long-term problems that can only be magnified by the current environment. In the midst of this turbulence, it could be valuable to know whether a set of shared problems may be hampering the ability of managers to cope with today's uncertainty. Given that a common set of problems may elicit industry-wide solutions, I undertook the study reported in this article to elicit a broad range of perspectives on the following simple question: What one or two problems or concerns are most troubling to you as a manager?

Human resources, still. As I describe below, the study found that the fundamental issues of recruiting and retaining skilled employees continue to be the most important concern on the minds of many operators, while the specter of government regulation is also a major problem-notably as part of the ongoing debates over obesity. As explained in this article, the human resources challenge seems particularly thorny. The critical nature of human resources is consistent with previous research that has identified key issues of concern for lodging managers. ${ }^{1}$

While times of prosperity would seem to be ideal for making bold changes in an operation, instead complacency often sets in. Changes and initiatives often do 
not occur until a period of crisis arises. It is ironic that the motivation to do something different and to make radical revisions to current practice is strongest in those periods of greatest stress, when change is most difficult and resources are stretched. The key issues of concern reported in this article were gathered to help the industry begin considering the areas in greatest need of rethinking and possibly change.

\section{Study Method}

To identify the most troubling problems for restaurant managers, an openended survey was administered to members of the National Restaurant Association via the association's newsletter and Cornell University's Web site. A total of 448 restaurant operators, senior managers, and owners responded to the survey. Responding to an open-ended survey format, managers were asked to think about the one or two issues, problems, or concerns that they find themselves worrying about or wishing that they had a better way of handling or addressing. This broad question was used to determine what was on managers' minds without directing them to a particular answer or forcing them to select from a list of already identified issues. In addition, the managers were given space to elaborate on their concerns. It is important to note that this study was not designed to be a representative qualitative analysis of all restaurant owners and managers. Rather, the approach relied on qualitative research intended to elicit categories of issues that are pressing to owners and managers.

Elements of grounded theory serve as the foundation for this qualitative field survey. As qualitative researchers have suggested, the value of understanding lies in grounding theory in the data (as opposed to speculative and abstractly formulated ideas). ${ }^{2}$ The methodology used in this survey is in keeping with the recommendations of qualitative scholars who note that initial questions should be broad to allow one to understand how and why managers view a particular issue. ${ }^{3}$ As noted in a recent Cornell Hotel and Restaurant Administration Quarterly article, "Qualitative research refers to an interpretative method of collecting and analyzing data to explore and explain a phenomenon."

In this study, the data from the surveys were analyzed using a three-step procedure, consistent with approaches recommended by many researchers. ${ }^{5}$ First, all the written responses were read in whole to obtain a feel for content. Next, keywords from the written comments were placed into common categories and subcategories. These classification criteria were determined in keeping with guidelines established in the qualitative research literature that note that the criteria for coding should include the researcher's experiential knowledge and learning established from the research progression and prior studies. The combination of experience, learning, study frameworks, and insights enables the researcher to construct an interpretation framework around an issue. A key point is that this protocol permits themes to emerge from the data and does not force the issues into preconceived categories.

Following the coding process, I examined the similarities and differences among comments. These classification and comparison processes are the precursors to the summary statistics and frequency distributions that I present later in this article. In the study reported here, I rely on the patterns and themes that emerged across all the responses. The ideas and insights yielded major issues of concern, along with subcategories of frequently mentioned items. 
Many independents. Of the 448 individuals who responded to our survey, the typical respondent was a male owneroperator (60 percent) in his late forties (forty-nine years old) with twenty-four years of industry experience. Most of the managers who responded worked in fullservice operations ( 70 percent) that were owned by partnerships ( 62 percent). Presidents and senior managers also represented a substantial portion ( 24 percent) of survey respondents, with unit managers and regional or district managers constituting only 5 percent of the total (see Exhibit 1). ${ }^{6}$ It is important to note that the independent restaurant operator of fullservice concepts is the primary respondent to this survey. When differences were observed between owner-operators and managers or ownership types, the data were broken down into separate groupings according to these characteristics.

\section{Problems on Your Mind}

By asking managers to identify just the one or two issues or problems that they find themselves worrying about most or wishing that they had a better way of addressing, this qualitative study revealed several salient themes. (See the sidebar on pp. 319-320 for the entire list of issues and their frequencies.) The analysis revealed that by far the most frequent problems to emerge revolved around issues of human resources management (cited by 36 percent of respondents) and government regulations (25 percent). Six additional groups of problems surfaced, but as Exhibit 2 shows, the managers whom we studied did not mention the issues of food handling, marketing, operations, the economy, competitive dynamics, or accounting nearly as often as they cited human resources. Taken together, in fact, these six "minor" issues were mentioned by 39 percent of the respondents-or about the

\section{Exhibit 1:}

Respondent Profile

\begin{tabular}{lc}
\hline Number of respondents & 448 \\
Gender & \\
Female & $27.1 \%$ \\
Male & $72.9 \%$ \\
Average age & 49.4 \\
Average years in industry & 24.3 \\
Type of operation & \\
(percentage in each category) & \\
Full service & $70.1 \%$ \\
Limited & $21.7 \%$ \\
On site & $3.3 \%$ \\
Club & $3.1 \%$ \\
Cater & $11.2 \%$ \\
Bar & $4.0 \%$ \\
Other & $11.2 \%$ \\
Position in each category & \\
Owner-operator & $60.3 \%$ \\
President & $11.2 \%$ \\
Senior managers & $12.5 \%$ \\
Field managers & $4.5 \%$ \\
Other & $11.6 \%$ \\
Ownership types & \\
Sole proprietorship & $22.4 \%$ \\
Partnership & $61.8 \%$ \\
Private corporation & $8.5 \%$ \\
Public Corporation & $7.3 \%$ \\
\hline
\end{tabular}

a. Type of operation does not total 100 percent because respondents could select more than one.

same number as cited human resources. I discuss the human resources and governmental regulation issues first, and then I turn to the six lesser, but still critical, issues. Throughout this article, the actual statements and quotes of many of the managers who shared their concerns will be included to add richness to the coded data.

\section{Human Resources-}

\section{The Major Issue of Concern}

Imagine the following scenario. You have a competent and hardworking employee whom you would like to retain. Your firm does not offer health insurance, though, and this person gets a better job with good benefits and moves on quickly. 
EXHIBIT 2:

Human Resources Issues

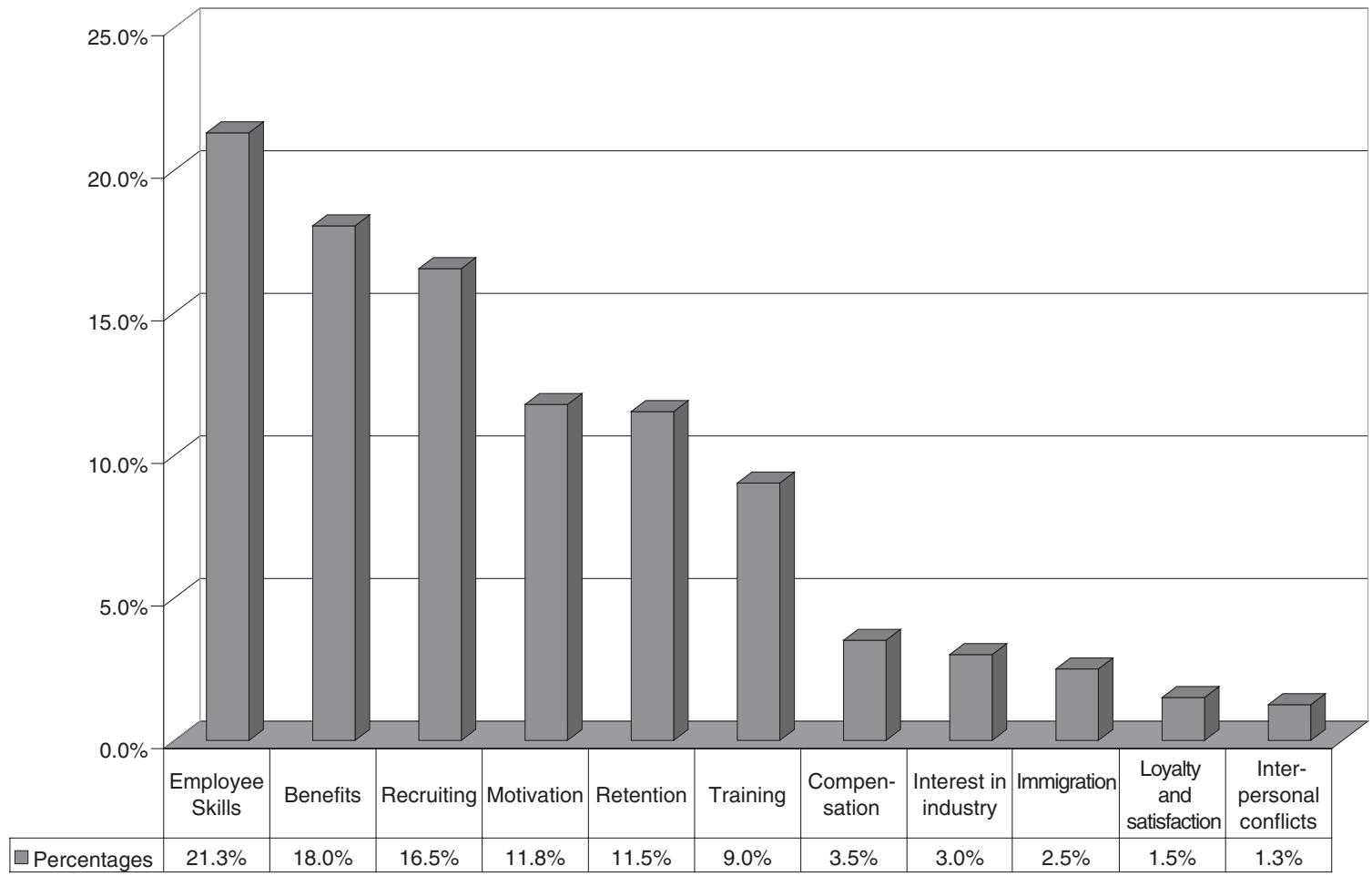

In contrast, you have other employees who have attendance problems, walk out during shifts, do not understand service, and do not have the needed skills. Worse, the rising minimum wage for these lowskilled and unmotivated employees makes it difficult for you to attract and retain the more desirable workers.

If this problem sounds familiar, you are like many of the managers in our study. Human resources management was the overwhelming area of concern for respondents. As shown in Exhibit 2, of those mentioning human resources concerns, 21 percent stated that employees' skill levels constitute the area of greatest concern. Careful analysis of the human resources issues reveals that other issues such as compensation and benefits, adequacy of training, and the image of the industry in attracting and retaining talent all contribute to the lack of skilled employees. As the scenario at the beginning of this section suggests, restaurants will be unable to attract or retain employees with appropriate skills if the industry is viewed merely as a place to work on the way to a "real" job, if employees are shown few new skills during training, and if it is difficult for an individual to support a family on the available wages.

"If unemployment is such a problem, where did all the applicants go?" wondered one survey respondent. Finding qualified and dependable staff members with the appropriate skills is a struggle for 
some operators, who noted that they never have enough employees and the labor pool from which they draw is poor. "Nobody seems to want to work in the food-service industry," noted a unit manager in a family-style restaurant. He added, "The hours are long, the work can be hard, and the pay can be average in some areas, yet potential employees are now able to pick and choose where they want to work. Most of these people choose the most amount of pay for the least amount of work."

The recruiting problem exists for positions at all levels. The back-of-house positions, which may require less skill than do those in the front of the house, pose special challenges because managers often rely on recent immigrants to fill many kitchen positions. Finding qualified management candidates is equally challenging, with half of the respondents who mentioned recruiting as a problem identifying the hiring of skilled managers as being a constant concern. Some blame the industry's image as a long-hours, low-wage occupation for contributing to the recruitment problem.

Numerous managers expressed the need to create an image of food service as a rewarding career to keep "good people" interested in the industry. One respondent expressed alarm at the small numbers of high school students who are interested in going into the food service industry. Another recommended that the industry at the national level should work to instill the view that food service is a profession and not something you do while waiting for your life to begin or as a fallback job. The problem with that position, however, was noted by another manager, who stated that industry owners and operators themselves do not take a professional attitude when it comes to their own businesses - a situation that makes it challenging to project a favorable industry image.

\section{Issues Cited by Restaurant Respondents}

\begin{tabular}{|c|c|}
\hline Key Issues & $\begin{array}{c}\text { Multiple } \\
\text { Frequency Count }\end{array}$ \\
\hline \multicolumn{2}{|l|}{ Human resources: } \\
\hline \multicolumn{2}{|l|}{44 percent of total responses } \\
\hline Employee skills & 85 \\
\hline Benefits & 72 \\
\hline Recruiting & 66 \\
\hline Motivation & 47 \\
\hline Retention & 46 \\
\hline Training & 36 \\
\hline Compensation & 14 \\
\hline Interest in industry & 12 \\
\hline Immigration & 10 \\
\hline Loyalty and satisfaction & 6 \\
\hline Interpersonal conflicts & 5 \\
\hline Subtotal & 399 \\
\hline \multicolumn{2}{|l|}{ Government regulations: } \\
\hline \multicolumn{2}{|l|}{28 percent of total responses } \\
\hline Health care insurance & 49 \\
\hline Rising minimum wages & 44 \\
\hline Taxation & 38 \\
\hline Insurance costs & 33 \\
\hline Estate tax & 3 \\
\hline Property tax & 4 \\
\hline Payroll tax & 3 \\
\hline Interference & 15 \\
\hline Paperwork & 8 \\
\hline Smoking bans & 10 \\
\hline Legal liabilities & 21 \\
\hline Obesity & 3 \\
\hline Tip restrictions & 16 \\
\hline Workers' compensation & 9 \\
\hline Subtotal & 256 \\
\hline \multicolumn{2}{|c|}{ Marketing: 7 percent of total responses } \\
\hline Advertising & 7 \\
\hline Sales management & 15 \\
\hline Customer retention & 8 \\
\hline Customer satisfaction & 2 \\
\hline Customer attraction & 10 \\
\hline Customer expectations & 5 \\
\hline Customer service & 10 \\
\hline Industry image & 6 \\
\hline Subtotal & (contin \\
\hline
\end{tabular}




\section{Issues Cited by Restaurant Respondents (continued)}

\begin{tabular}{|c|c|}
\hline \multicolumn{2}{|l|}{ Accounting: 7 percent of total responses } \\
\hline Cash-flow management & 5 \\
\hline Cost controls & 12 \\
\hline Labor costs & 19 \\
\hline Equipment cost & 1 \\
\hline Product waste & 2 \\
\hline Utility cost & 6 \\
\hline Rent cost & 4 \\
\hline Cost of sales & 2 \\
\hline Financing & 4 \\
\hline Profit & 10 \\
\hline Subtotal & 65 \\
\hline \multicolumn{2}{|l|}{ Food issues: 6 percent of total responses } \\
\hline Food safety & 25 \\
\hline Food sanitation & 10 \\
\hline Food handling & 2 \\
\hline Food trends & 7 \\
\hline Food costs & 8 \\
\hline Food allergies & 2 \\
\hline Nutrition-obesity & 3 \\
\hline Food quality & 4 \\
\hline Subtotal & 61 \\
\hline \multicolumn{2}{|l|}{ Economy: 3 percent of total responses } \\
\hline Slow economy & 14 \\
\hline Terrorism & 4 \\
\hline Labor pool shortage & 8 \\
\hline Seasonality & 3 \\
\hline Subtotal & 29 \\
\hline \multicolumn{2}{|l|}{ Competition: 3 percent of total responses } \\
\hline Competing with chains & 22 \\
\hline Dropping sales & 2 \\
\hline Subtotal & 24 \\
\hline \multicolumn{2}{|l|}{ Operations: 2 percent of total responses } \\
\hline Information technology advances & 3 \\
\hline Maintaining physical equipment & 3 \\
\hline Menu pricing & 0 \\
\hline Purchasing and vendor quality & 8 \\
\hline Administration work & 1 \\
\hline Organizational structure & 1 \\
\hline Subtotal & 16 \\
\hline Grand total & 915 \\
\hline
\end{tabular}

Note: Respondents were permitted to provide multiple issues in the frequency counts noted in this table, so numbers will not sum to 100 percent.
To retain good workers, the popular perception of the industry needs to be altered, said some respondents, and along that line several focused on the importance of providing appropriate compensation. Even more participants stressed improved benefits as a means of altering the industry's recruiting and image problems. "We need to figure out how food service can offer health-care benefits to the working poor," suggested one manager who was worried about finding and retaining good people. A similar sentiment was expressed by a different manager, who said, "We need to figure out a way to reward the hardworking people who work for us, so that they can provide a decent standard of living for their families." Another observed that executives make millions while employees make minimum wage or less.

Though many were distressed by their employees' work ethic (or lack thereof), others understood that the industry itself has contributed to staffing problems by failing to provide adequate benefits, reasonable training, and competitive wages. Interestingly, at the same time that some managers were reporting that workers lacked skills, motivation, a good work ethic, basic manners, honesty, and dependability, others focused on why they were getting such low worker effortmostly citing the lack of industry action to become more professional through training, compensation, skill building, and other incentives. That said, one manager noted that he found it difficult to expect 100 percent effort, enthusiasm, and engagement from young American workers. Settling for second best by just getting the job done captures another manager's description of his staff. All of these managers were struggling to determine what would attract good workers to the industry and what would be necessary to keep 
EXHIBIT 3:

Government Issues by Ownership Group

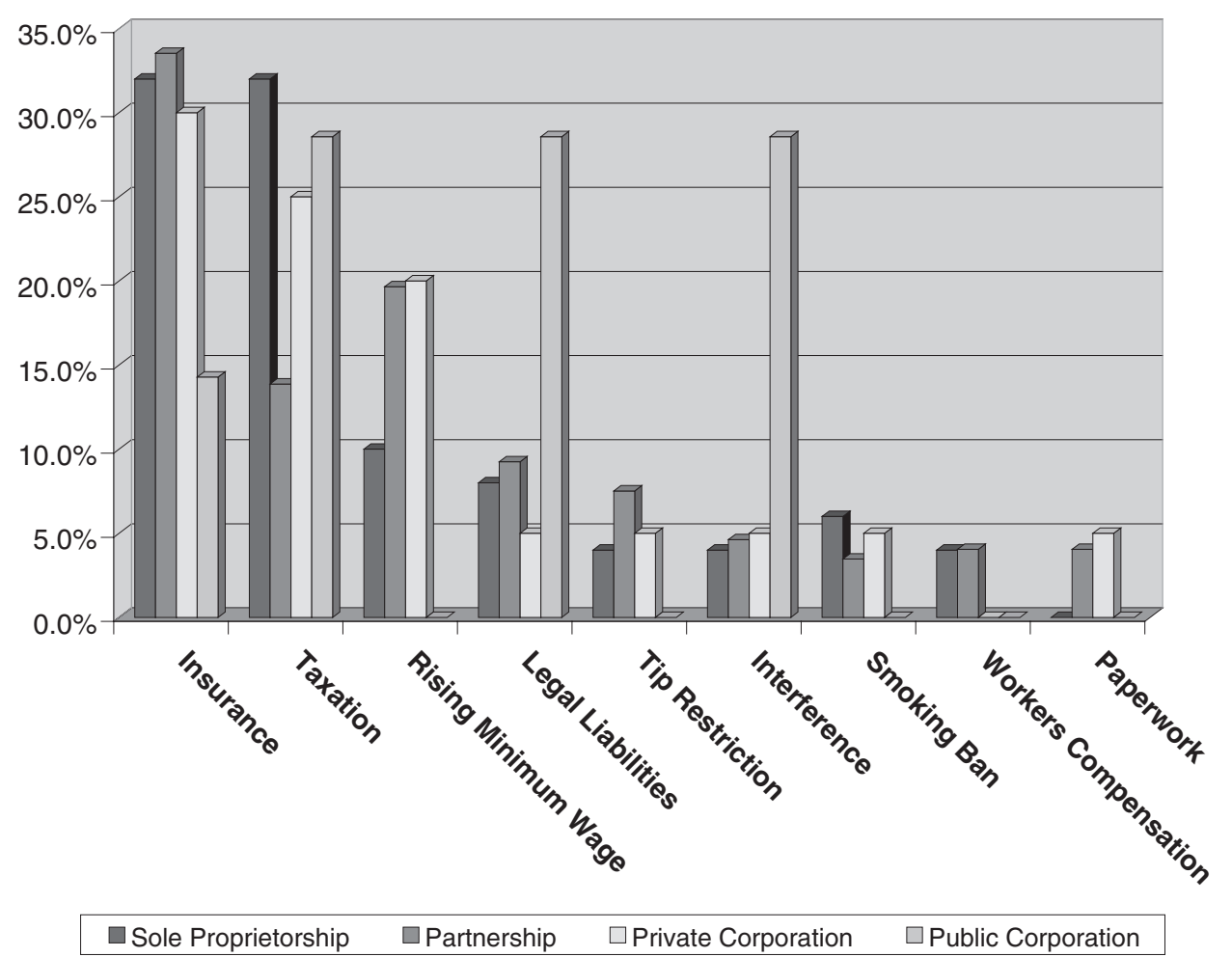

them. I now turn to the second most important issue identified in the studygovernment regulation.

\section{Government Regulations- One of Life's Certainties}

Taxation and regulation are issues of major concern to the food service industry. As Exhibit 3 shows, taxation and health care insurance are extremely worrisome. Exhibit 3 divides governmental issues into specific taxation and regulation issues according to four ownership categories. It is interesting to note that government interference is a shared theme, but the respondents worried about different facets of that overall theme, depending on the type of business they operated. Legal liability was of particular concern to man- agers in public corporations, especially lawsuits around obesity. As one operator of a quick-service restaurant expressed it, "Why not sue restaurants because they serve whole milk, or soda, or apple pie? None of them is good for you if eaten in large quantities." Others expressed concern about obesity in the context of public health and education. Representatives of public corporations were not as worried about property and payroll taxes as were individual operators (and, of course, estate taxes are not as big a factor for public companies as they can be for sole proprietors). Similarly, issues of tipping, added paperwork from reporting and record keeping, smoking bans, rising minimum wages, and workers' compensation expenses were issues for privately operated 
corporations and sole proprietorships but were not mentioned by respondents from public corporations.

Excessive government regulation is creating an unnecessary burden on the industry. This was the clear message of the many managers who cited regulation and taxation as being a challenge. Individuals in legislative positions or government agencies were viewed as lacking a clear understanding of the industry's narrow operating margins or the reasons why restaurants typically fail. Profits for some are not keeping pace with the current annual increases in expenses stemming from regulation and taxation. A respondent from Oregon noted, "Our liberal state constantly finds ways to tax the hospitality industry. With a profit margin of 3 to 7 percent and measures on the November ballot

Restaurant operators agree: human resources is the industry's biggest problem. But they cannot agree on how to fix it.

exceeding that percentage, [legislation] is destroying the industry." Several expressed the feeling that various government entities were indifferent to their problems and that the small-restaurant owner was helpless to resist additional government intervention. One respondent expressed it this way: "Local, town, county, state, and federal-multiple agencies at each level [show a] seemingly inyour-face attitude, knowing we have little or no resources to fight them without repercussion." A call for tax law reform was voiced strongly by those who were in sole proprietorships and partnerships. Property taxes, estate taxes, and payroll taxes were all identified as onerous for small and medium-size businesses. Overall, taxation was a topic of major concern for all ownership groups but was most strongly expressed by public corporations.

A large percentage of respondents from privately operated organizations talked about the burden of increasing minimum wages, although a few noted that the "minimum wage is an insult" and that even when raised, it does not suffice to cover the ever-increasing cost of living for the young and informed worker. Then again, state and local efforts to tie the minimum wage to the consumer price index or to raise it on a mandated or automatic schedule drew criticism from respondents. Others noted that minimum wage differentials exist for small businesses, but no accommodation is made for medium-size businesses that must follow the same regulations as large chain restaurants. Note that managers from public companies did not express concern about the rising minimum wage, perhaps because these businesses enjoy slightly higher profit margins than do independent operators. In addition, some argued that the negative image of the industry was a function of paying so little to workers and asking them to work long hours without health care coverage, as noted earlier in the discussion of human resources.

Tipping was another hot topic for respondents from privately owned or operated firms. Many expressed resentment that the government was imposing an obligation on the restaurant to ensure that employees report their tip income. Several suggested that the United States should reduce the complexities of managing the tipping issue by adopting the European practice of fixed service charges. The pay inequity of tipped versus nontipped employees was also noted as a constant 


\section{EXHIBIT 4:}

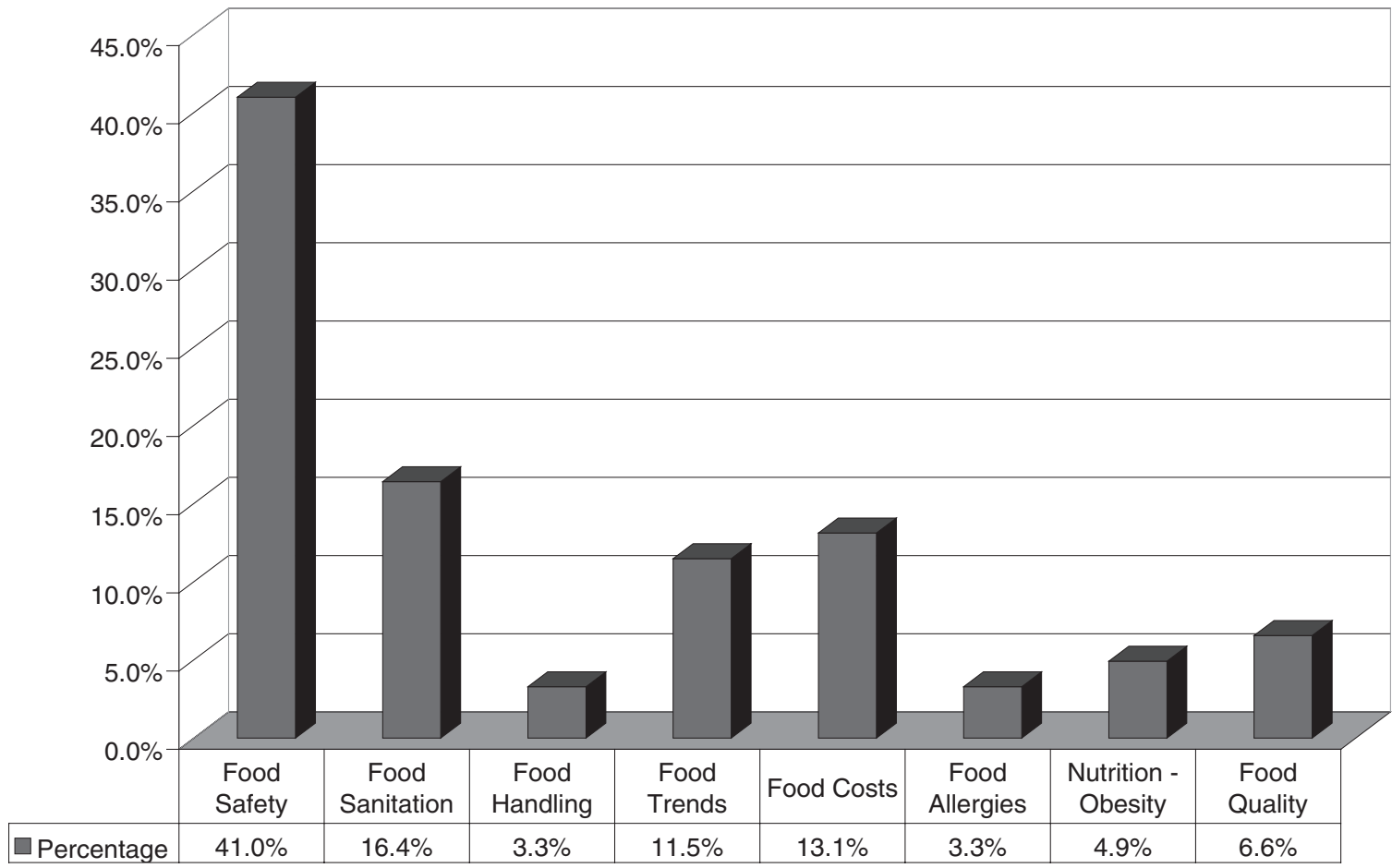

source of friction and something that requires the industry's attention. Finally, smoking bans were mentioned, albeit to a lesser degree than were other regulations. Respondents commented on both sides of that issue, with some suggesting that such bans will harm their business and others hoping that their state will follow California's and New York's lead and prohibit all smoking in restaurants. Note that respondents from public corporations did not mention smoking bans, tipping restrictions, or specific taxes.

Rising insurance costs, particularly for health and for property and casualty insurance, were also major issues within this category. Government interference was cited again in reference to mandatory insurance benefits. The costs of insurance programs are repeatedly noted as cost- prohibitive, placing many managers in a conflict between wanting to provide the best benefits they can for workers while feeling the profit pressures. Small operators in particular were concerned about their ability to compete against large chain operators in the areas of employee benefits, especially affordable health insurance for hourly workers.

\section{Food Safety and Security Issues}

In this and the following sections, I discuss the six issues that were cited less frequently than were human resources and government interference. Managers identified a variety of food-related issues that concerned them (see Exhibit 4). Forty-one percent of food issue responses involved the vexing challenges of food safety, a category comprising supply, preparation, 
cooking methods, storage, and serving. Protecting the food supply from the field to the restaurant, and incorporating safe food practices into restaurants to prevent accidents or illnesses, were noted by many respondents. Managers spoke with some alarm about current farm practices, while others suggested that preservation and diversification of domestic farm production and stabilizing ocean harvesting were important issues. Still others identified the challenge of maintaining food safety standards with franchise restaurant owners.

Food sanitation was mentioned in the context of biological terrorism and how to prevent contamination, while some expressed concerns about food-borne illnesses and how best to manage public relations and determine whether procedures were the true cause of a complaint. Making Hazard Analysis Critical Control Points (HACCP) work in various restaurant contexts, such as high-volume whitelinen operations that do not use frozen or premade foods, was another example of a food issue that challenges managers. Identifying foods that contain transgenic components is yet another worrisome issue. Controlling food costs and ensuring that the best possible food products are purchased are also of considerable importance to many managers. Bioengineering of food, irradiation, and the changing American diet were noted as challenges for the industry. ${ }^{7}$ Obesity was noted in the context of food trends and the development of healthy foods and exploring alternative cooking methods. The balance between improving product quality while managing the higher costs of fresh products and the complexities of storage were noted in particular. In summary, while food safety was the most critical issue in this area, food sanitation and handling were mentioned, as were controlling food costs, food quality, and nutrition.

\section{The Economy and Competition}

The uncertainty of the economy, terrorism, and the conflict in Iraq all contribute to feelings of anxiety, and the respondents worry that consumers will stay home rather than eat out. Exhibit 5 shows the four most troubling economic issues, with the economy by far the major factor identified by managers. One respondent cited economic issues as hampering the ability to initiate expansion plans that are warranted. Powerlessness and frustration are cited as outcomes of the external realities of the current economy.

The economy is troubling but difficult to change. As a consequence, managing what you can control appears to be the only viable approach for handling this challenge. Along with a distressing economy are the dynamics of competition, including franchising, branding, maintaining increases in same store sales, and pricing behavior.

Two types of competitive issues surfaced in the survey-namely, competing with large, multibrand, multiunit chains and, to a much smaller degree, dropping sales. Finding the right niche and maintaining a reasonable profit margin are competitive challenges for many who observe the increase in the number of chain units. New chain restaurants are flooding the market for casual dining, according to some respondents, and thus increases in restaurant supply have caused earnings growth to decline for small businesses. Independent restaurants in particular noted the challenges of surviving rising costs and an inability to raise prices, questioning whether they can coexist with the chains. For those with a seasonally fluctuating business, another competitive 


\section{Exhibit 5:}

\section{Economy-Related Issues}

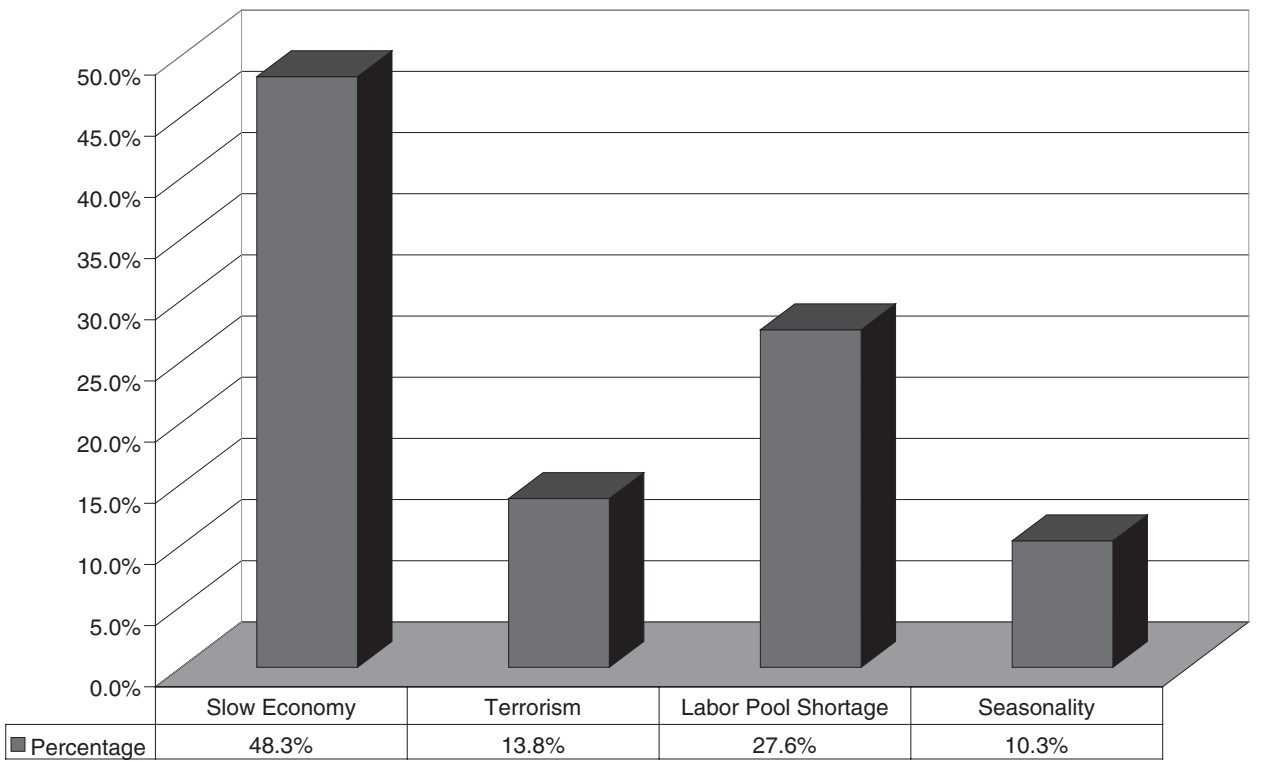

challenge is increasing off-season business to maintain profitability.

\section{Accounting and Operations}

Managing escalating costs was identified as a key accounting issue for 71 percent of the managers responding to this survey. Labor, rent, utility, product waste, and equipment costs were all mentioned as examples of the escalating costs that burden many managers. As one respondent noted, "We're in California. Most of our concerns are cost based. Take your pick: rising labor, rising insurance costs, rising energy costs, rising administrative costs, rising legal costs." In addition to cost issues, cash-flow management, financing, and profitability emerged as challenges.

Exhibit 6 summarizes the major accounting issues for owner-operators separately from all other groups of manag- ers, with a detailed breakdown of specific cost issues. This analysis shows that labor costs are a key issue for everyone (including presidents and senior managers), but the challenge of sustained profitability is felt most strongly by owner-operators. Cash-flow management and financing were also identified as key accounting issues, but only for owner-operators, while all other managers stressed labor costs and cost controls. Numerous owners indicated that banks are increasingly reluctant to provide loans to restaurants, or, as one owner of a casual-dining restaurant noted, "Bankers do not want to help you anymore." A similar sentiment came from the owner of a family-dining restaurant, who stated in his survey response, "Bankers don't think that a restaurant is a business."

Operational issues constituted the least cited area of concern in this study. At last, 
Exhibit 6:

Accounting Issues

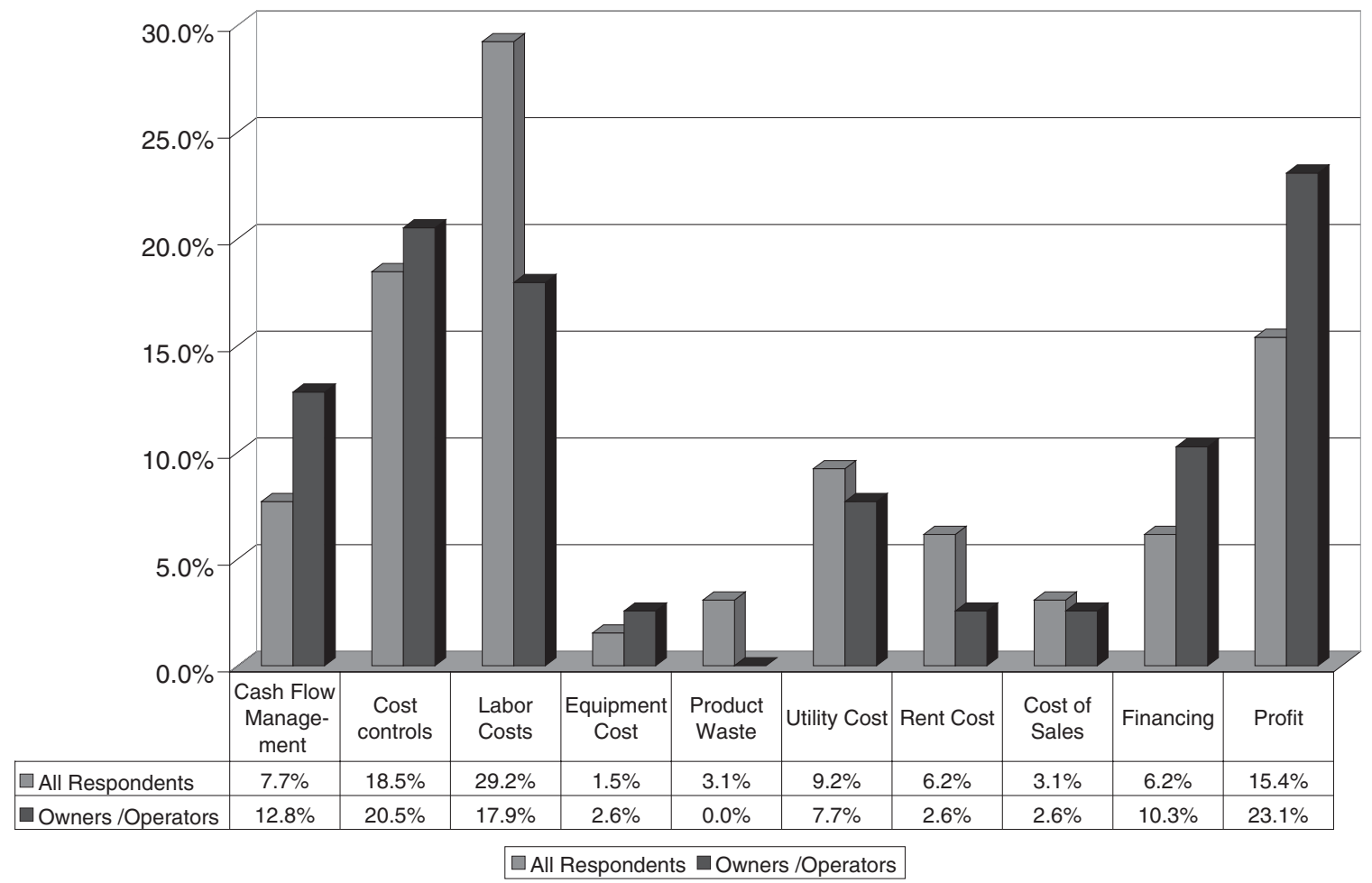

here is something over which restaurant operators have reasonable control. Nevertheless, even in this area the respondents cited specific problems, in particular purchasing and vendor quality, followed by information technology advances and maintaining or upgrading physical equipment. The chief vendor issue is consistency of service, which is particularly troublesome for small operators. Suppliers' food quality - specifically, that of seafood vendors-was another aspect of operational concern.

Two lesser operations issues were menu pricing and organizational structures. Menu pricing was mentioned in the context of trying to determine when the public will avoid a restaurant because its prices have become too high. Organizational structure concerns were based on larger operators' challenges to design their organizations to ensure optimal organizational functioning. Perhaps the reason that operational issues were on the whole identified as challenging in only 3 percent of total responses is that these problems are more easily handled than are many of the others that respondents cited.

\section{Sales Management and Marketing}

A variety of marketing issues emerged, with advertising, customer attraction, sales management, and customer service at the top of the list. Customer retention, the poor image of the industry overall, 


\section{Exhibit 7:}

Marketing Issues for All Respondents and Owners/Operators

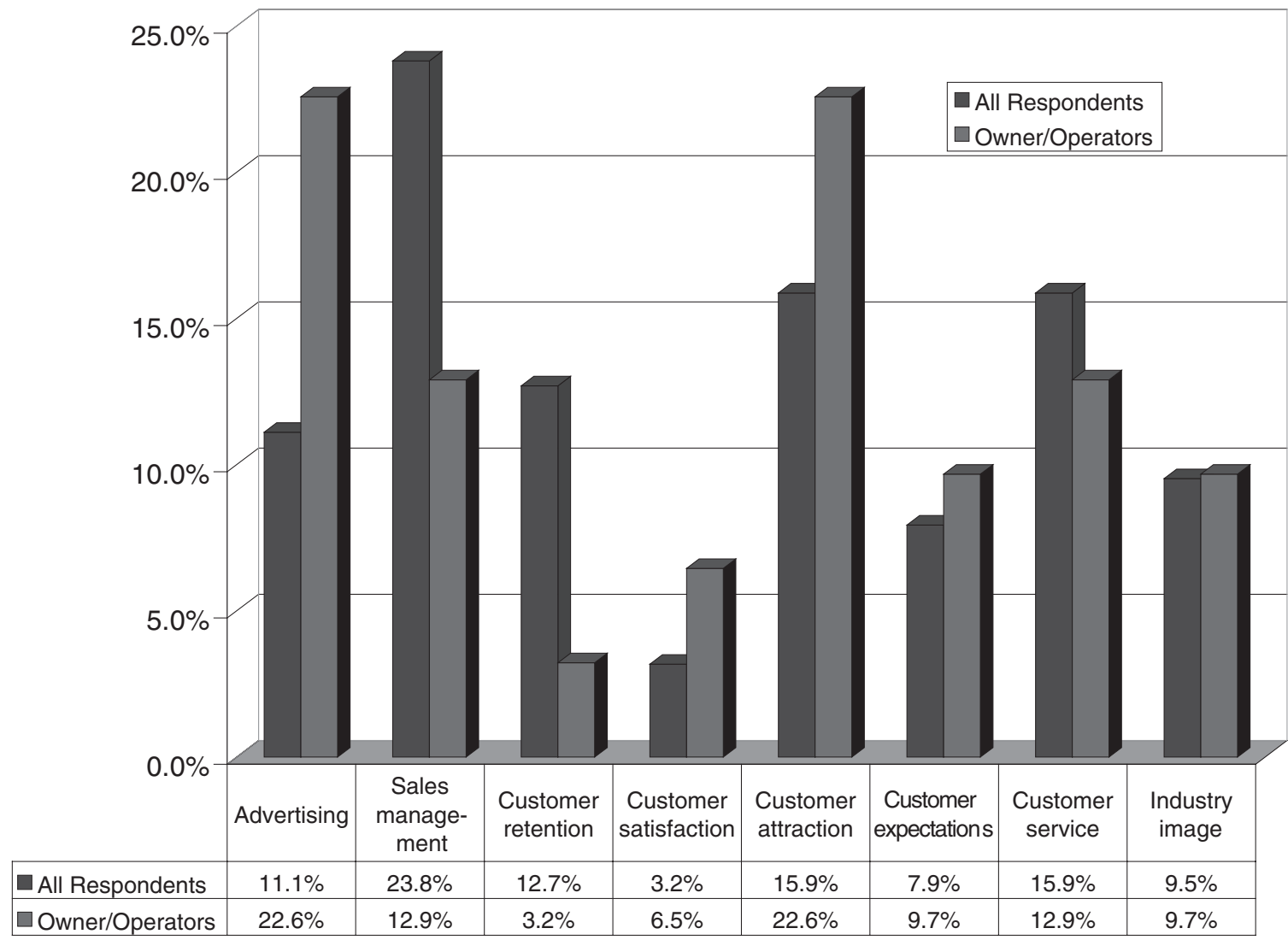

changing customer expectations, and customer satisfaction round out the list of issues shown in Exhibit 7.

As Exhibit 7 reveals, advertising was at the top of the list for owner-operators, while presidents, senior managers, and field managers stressed sales management. "Advertising is not working," was the sentiment expressed by one owner of a family-dining restaurant. Advertising issues included such challenges as advertising to the unemployed, to Hispanic markets, and to people who do not read newspapers or listen to radio. Adjusting to the changing demographics in immediate local neighborhoods and developing a successful overall advertising campaign were high on operators' lists.

Some respondents criticized the industry itself for advertising fresh ingredients when, in fact, foods contain preservatives and are shipped frozen and microwaved on site. Overall, the advertising challenge for single-unit operators appears daunting, while sales-management issues are a problem for all types of operators and managers.

Increasing sales in highly competitive markets during difficult economic times is the sales-management challenge. A puz- 
zle for many who responded is how to increase the volume of customers coming into their restaurants. Keeping up with customers' expectations as customers continue to demand novel, inexpensive, and intriguing food offerings was noted by many. Some felt that customers' expectations had become unreasonable, while others argued that managers need a better understanding of demographic trends to help overcome the sales-management challenge. Still others argued that the guests' mentality and perception of value had eroded and that guests have lost touch with the dining experience.

The need for better tools to capture customers' feedback before they leave the restaurant was identified as necessary to help in the process of attracting and retaining customers. In addition, a better understanding of customer satisfaction with regard to the dining experience was suggested to help deliver high-quality service. Many respondents seemed frustrated with evolving customer expectations and understanding of the dining experience but particularly with regard to discovering how to keep them content and coming back.

\section{The Need for Change}

As indicated at the outset, periods of challenge may be the needed catalyst for change. The quotes used throughout this article provide a glimpse into how operators express their concerns, and these comments reveal that many operators feel helpless to alter the current situation. Exhibit 8 combines several of the most frequently mentioned issues to offer a fuller picture of what is troubling the industry.

As Exhibit 8 illustrates, the industry remains extremely competitive, with rising customer expectations and demands for high-quality dining experiences and service. Keeping customers satisfied and coming back depends in large measure on the quality of customer service. A large body of existing research reveals that when employees consider an organization's human resources policies as being positive, customers tend to view more favorably the quality of service provided. ${ }^{8}$ Furthermore, customer satisfaction leads to profitability. Hence, a restaurateur's inability or unwillingness to develop good human resources practices is likely to lead to lower customer satisfaction and lower financial success. ${ }^{9}$ Clearly, service quality and, ultimately, profit depend on the skills and abilities of employees, which is why it is no surprise that the survey revealed that employees' performance was the most vexing problem for restaurants. To provide additional employee benefits or compensation raises labor costs and makes it hard to keep prices competitive and maintain profit margins, particularly for the independent operator. Pressure from demanding customers to provide highquality products and service at a competitive price leads many managers to focus on controlling and reducing labor costs while lamenting the poor service delivered by the employees they can retain. Unfortunately, implementation of laborcost controls often results in de-motivated, disloyal, and unsatisfied workers who tend to leave when better-paying jobs become available.

In addition, other, external factors pose a challenge to the industry. Local, state, and federal governmental agencies worried about the working poor introduce legislation that increases the costs of doing business, such as minimum wage and health insurance regulations. In New York State, for example, the legislature is considering raising the minimum wage from $\$ 5.15$ to $\$ 7.10$, which would give a fulltime worker an annual salary slightly 


\section{Exhibit 8:}

A Model of Key Issues

\section{Competition}

Customer Service Quality and Retention

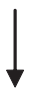

Key Problems of the Industry

Employee Issues of Concern $\longrightarrow$ Industry Image

Labor costs Interest in working in the industry

Health-care insurance Work conditions (e.g., long hours)

Benefits Low wage

Worker compensation Low skill

Minimum wages Limited growth opportunities

Skills and abilities

Food sanitation and handling

Compensation

Attracting

Retaining

Motivating

Training

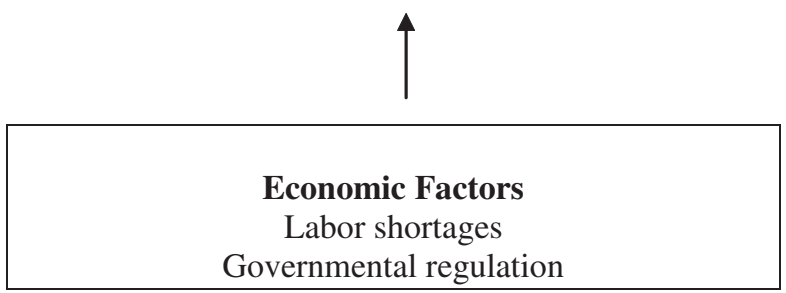

below the federal poverty threshold of $\$ 14,679$ for a family of three. ${ }^{10}$ Some of the respondents in this study supported raising the minimum wage, but a much larger group who mentioned this issue expressed opposition because their costs would increase. It appears that while universally respondents opposed government intervention, they were also unable or unwilling to introduce additional employee benefits or compensation without a government mandate.

The tension between enhancing customer satisfaction by investing in employees and the need to control the costs that would accompany increased wages and added benefits is perhaps why the human resources problems are the most pressing and unresolved for restaurateurs. In the middle of Exhibit 8 is a set of human 
resources problems and practices that have the net effect of harming the image of the industry - a constellation that contributes to the problem of labor shortages, even during a period of high unemployment. A key problem is that the low wages, meager benefits, limited training, and long hours lead to high turnover, an unstable workforce, poor service delivery, and the impression that the industry is an undesirable employment option for the long term. The government intervenes to mandate higher minimum wages and health insurance to improve the quality of lives for workers, causing the small operators to struggle with even smaller profit margins. Customers come to believe they get what the industry pays for, which is low-skilled and de-motivated workers who provide poor service.

The survey revealed that many operators and managers complained about high labor costs while also being puzzled about why customers were unsatisfied and no skilled workers could be found. Sadly, some operators and managers seem to have set up their operating systems with the assumption of low skills, high turnover, and low motivation. If that is the case, such structures would hinder the industry's ability to resolve its longrunning human resources challenges. In place of a mind-set that accepts low wages and poorly trained employees as a facet of the industry's environment, the industry could seize the opportunity of a lackluster economy to restructure for the inevitable growth to come. Several respondents offered remedies to the current problems, but many of the small, independent operators felt that they lacked the size and resources to tackle these problems alone.

Instead of wondering why young managers and workers are not loyal, managers could determine how to foster loyalty, possibly through creative wage and bene- fit policies. Running a business in a competitive environment is a challenge in and of itself, but the failure to invest in people is at the heart of the bad image and ongoing service problems the restaurant industry faces. The view of employees as costs to be managed rather than key investments for the long-term competitive success of the restaurant is one reason that the image of the industry suffers, customer service is low, and the government intervenes with legislation. What would happen if the industry began to take the development of people seriously, particularly the small business owner and operator? For the industry to enhance its image, a unified, industry-wide set of activities and practices is needed.

A National Restaurant Association study suggested that the industry must become an employer of choice if it hopes to satisfy customers and increase profit. ${ }^{11}$ Realizing that service problems have plagued these operations and deserve attention, large multiunit restaurant chains have aggressively begun to develop customer service training (see the sidebar on p. 331 on Yum! Brands). In addition, a recent study of twenty-eight restaurants in a regional chain revealed being an employer of choice yielded high customer satisfaction. ${ }^{12}$ In short, attention to human resources practices can pay off in customer satisfaction and ultimately profitability.

Although I asked the respondents of this study to focus their attention on problems rather than remedies, several suggestions were offered, as noted throughout this article. To begin a serious approach to addressing the ongoing issues that surfaced in this study, more time and energy should be spent examining how to remedy human resources issues. To stimulate future reflection on these issues, the 
industry might consider some of the following activities and practices.

- Support for increases in minimum wages. Offering competitive compensation could help reduce turnover and improve the image of the industry as an employer. Lobbying against increased minimum wages conveys to the general population that the industry does not care about the quality of life for its lowest-level employees.

- Creative development of health care and additional employee benefits. Innovative approaches to reducing health care costs while ensuring that employees and their families are taken care of should be a major priority. It is difficult to sell the industry as an "employer of choice," to say nothing of being a profession, if fundamental needs are not accommodated.

- The reduction of excessively long work hours for employees. While smallbusiness operators are often devoted to their own entrepreneurial ventures and work excessive hours, employees not only fail to reap the same benefits but burn out unless their work schedules are carefully and effectively managed. Long work hours for some employees are often the result of failed human resources practices that result in excessive absenteeism and understaffing. The turnover that often creates long hours for existing employees also contributes to increases in replacement and training costs.

- The rethinking of jobs and responsibilities to produce more efficient operating structures. Through creative redesigning of jobs, outsourcing, and revised operating processes, traditional tasks could be reengineered.

- Training, career development, and planning for managers. Attention to building a future for young managers is one key to professionalizing the industry. Human resources strategy experts develop leadership competency models and devise plans for helping managers progress and advance. ${ }^{13}$ More attention to managerial skill building in areas such as problem solving and conflict

\section{The CHAMPS Program at Yum! Brands}

With 750,000 associates worldwide, customer service training is a key priority for Yum! Brands. Yum! Brands, a major player in the fast-food segment of the industry, is the world's largest restaurant company, with 33,000 outlets in more than 100 countries. The company has developed a "Customer Mania" program to guide training in customer service called CHAMPS. CHAMPS stands for Cleanliness, Hospitality, Accuracy, Maintenance, Product Quality, and Speed.

The skills that managers are teaching the frontline team members include how to listen to the customer, how to be empathetic to customer needs, how to exceed expectations within reason, and how to recover from mistakes. One Taco Bell restaurant manager from Florida described the chain's Customer Mania program as follows:

Customer Mania has provided us with a super edge in hiring great team members and in keeping the great ones we've put so much effort into training. We're building a reward and recognition culture, one that gets our team pumped up and excited about satisfying each and every customer. It's a great culture we're creating and it makes a big difference in the store day to day and makes people want to stay.

The program includes a CHAMPS Excellence review, in which 150 of the company's best managers are sent out to the restaurants to inspect the stores and ensure that the CHAMPS standards are being met. The company has made an $\$ 18$ million investment in this training program in the hopes that it will give the firm a competitive advantage. At Yum! Brands, this training is conducted four times a year and is viewed as a permanent commitment to quality.

Source: The information contained in this sidebar is drawn from C. Enz, "Multi-Branding at Yum! Brands Inc.: Thinking outside the Bun," in Hospitality Strategic Management: Concepts and Cases, ed. J. S. Harrison and C. A. Enz (New York: John Wiley, 1995), 469-82.

management could enhance the talent pool of industry leaders.

While some of these activities may be under way in certain communities, others are not, and the overall impression of the industry as an attractive employer and a viable profession needs more collective energy. In conclusion, the crisis of finding and retaining skilled workers could be considered an opportunity to revolution- 
ize current human resources practices. Addressing the key issues identified in this study, whether by individual owners and managers, or through concerted actions of organizations representing the industry's interests, might be a way to move restaurant operations toward a sustainable competitive advantage.

\section{Endnotes}

1. See Cathy A. Enz, "What Keeps You Up at Night? Key Issues of Concern for Lodging Managers," Cornell Hotel and Restaurant Administration Quarterly 42, no. 2 (2001): 38-45.

2. For a full discussion of grounded theory, see Anselm Strauss and Juliet Corbin, Basics of Qualitative Research: Techniques and Procedures for Developing Grounded Theory, 2nd ed. (Thousand Oaks, CA: Sage, 1998); and H. Blumer, Symbolic Interactionism (Englewood Cliffs, NJ: Prentice Hall, 1969).

3. For a hospitality focused discussion of fieldbased qualitative research, see Kate Walsh, "Qualitative Research: Advancing the Science and Practice of Hospitality," Cornell Hotel and Restaurant Administration Quarterly 44, no. 2 (2003): 66-74.

4. Ibid., 67.

5. Kathleen Gerson and Ruth Horowitz, "Observations and Interviewing: Options and Choices in Qualitative Research," in Qualitative Research in Action, ed. Tim May (London: Sage, 2002), 199-224; and Shay Sayre, Qualitative Methods for Marketplace Research (Thousand Oaks, CA: Sage, 2001).

6 . To determine whether the sample was representative of the membership of the National Restaurant Association (NRA), senior staff of the NRA were contacted to compare the respondent profile with the profile of their membership. After examining the profile described in Exhibit 1, they indicated that the sample characteristics were consistent with those of their membership.

7. For a discussion of just one example of dietary issues, the so-called "low-carb" craze, see Howard Riell, "Are Low-Carb Diets Here to Stay?" The Consultant 37, no. 1 (2004): 51-54.

8. D. A. Tabsik, "Managing Human Resource Issues for High-Contact Service Personnel," in Service Management Effectiveness: Balancing Strategy, Organization and Human Resources, Operations, and Marketing ed. D. Bowen, R. Chase, and T. Cummings (San Francisco: Jossey-Bass, 1990).

9. J. L. Heskett, W. E. Sasser, and L. A. Schlesinger, The Service Profit Chain: How Leading Companies Link Profit and Growth to Loyalty, Satisfaction, and Value (New York: Free Press, 1997).

10. R. Gilbert, "Disgrace: Time to Shrink Wage Gap," Ithaca Journal, March 9, 2004, p. 9A.

11. Foodservice Research Forum, Industry of Choice (Chicago: Educational Foundation, National Restaurant Association, 1997).

12. D. Koys, "How the Achievement of HumanResources Goals Drives Restaurant Performance," Cornell Hotel and Restaurant Administration Quarterly 44, no. 1 (2003): 17-24.

13. For a detailed discussion of building competency models for leaders, see B. ChungHerrera, C. Enz, and M. Lankau, "Grooming Future Hospitality Leaders: A Competencies Model," Cornell Hotel and Restaurant Administration Quarterly 44, no. 3 (2003): 17-25.

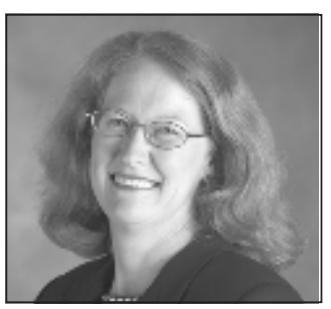

Cathy A. Enz, Ph.D., is the Louis G. Schaeneman Professor of Innovative Management at the Cornell University School of Hotel Administration (cae4@cornell. edu). The study on which this article is based was made possible through the collaborative efforts of the National Restaurant Association and the Center for Hospitality Research (CHR) at Cornell University. Special thanks go to Joseph Strodel of the CHR and Masako Taylor, a Ph.D. candidate at the School of Hotel Administration, for their assistance in this study. 